\title{
Element Order
}

National Cancer Institute

\section{Source}

National Cancer Institute. Element Order. NCI Thesaurus. Code C82506.

The order in which elements are org anized within an arm of a clinical trial. 